\title{
Interactions between nutrients, phytoplankton growth, and micro- and mesozooplankton grazing in the plume of the Mississippi River
}

\author{
Hongbin Liu*, Michael Dagg \\ Louisiana Universities Marine Consortium, 8124 Highway 56, Chauvin, Louisiana 70344, USA
}

\begin{abstract}
In March 2002, we conducted 6 shipboard grazing experiments spanning locations from near the largest discharge point of the Mississippi River to a far-field, high salinity location approximately $60 \mathrm{~km}$ to the SW. Waters were characterized by salinity, nitrate and size-fractionated chlorophyll a (chl a). None of our stations were in truly oligotrophic conditions typical of the open Gulf of Mexico. Experiments measured growth of 3 phytoplankton size categories $(<5,5$ to 20 and $>20 \mu \mathrm{m})$ and associated microzooplankton and mesozoplankton grazing. Rates of phytoplankton growth in all size categories were high in the near- and intermediate-fields, but declined dramatically in the farfield due to nutrient limitation. Microzooplankton grazing rates were low in the near-field, highest in intermediate stations and then declined in the far-field. The mesozooplankton grazing rate was generally low compared to the microzooplankton grazing rate. The mesozooplankton grazing rate was highest at the far-field station where more than $86 \%$ of daily growth of $>20 \mu \mathrm{m}$ phytoplankton was consumed by mesozooplankton. As the plume dispersed and mixed with higher salinity shelf water, inorganic nutrients became exhausted and phytoplankton growth (especially the large diatoms) became nutrient-limited. During this transition, the microzooplankton grazing rate surpassed the phytoplankton growth rate, causing a decline in phytoplankton biomass. Mesozooplankton grazing enhanced this decline by adding an additional grazing mortality, especially to the large phytoplankton cells. The dynamics between growth and grazing mortality in the different size fractions of the phytoplankton community, combined with varying growth rates associated with declining nutrient concentrations, and superimposed on a background of dilution derived from mixing of plume waters with oligotrophic oceanic water, makes interface regions between large rivers and the ocean exceptionally complex.
\end{abstract}

KEY WORDS: Phytoplankton growth - Microzooplankton grazing - Mesozooplankton grazing · Mississippi River plume $\cdot$ Trophic cascade $\cdot$ River-ocean interaction

\section{INTRODUCTION}

The Mississippi River is one of the world's 10 largest: it is approximately $6260 \mathrm{~km}$ in length, its average freshwater discharge into the northern Gulf of Mexico is $380 \mathrm{~km}^{3} \mathrm{yr}^{-1}$, and fresh and salt water mixing takes place on the continental shelf rather than in an estuarine embayment (Meade 1996). The drainage basin of this system covers more than $40 \%$ of the continental USA, an area equivalent to $3.34 \times 10^{6} \mathrm{~km}^{2}$ (Berner \&
Berner 1987). Receiving waters originate from the open Gulf of Mexico, a permanently stratified, oligotrophic subtropical sea. In addition, concentrations of dissolved nitrate found in Mississippi River water are typically >100 umol (Dagg \& Whitledge 1991, Turner \& Rabalais 1991) which, combined with low concentrations of dissolved nitrate in the permanently stratified waters of the open Gulf of Mexico, result in a continental shelf ecosystem that is biologically dominated by river inputs (Lohrenz et al. 1999). The region of inter- 
action between river water and the receiving waters of the northern Gulf of Mexico is highly dynamic and variable, and processes are complex and not fully understood.

Common features in this river-dominated system include: (1) A low phytoplankton growth rate in the river, attributed to high turbidity and strong mixing; (2) enhanced phytoplankton growth in the near-field plume region, attributed to an improved light environment associated with strong stratification and settling of lithogenic riverine materials; (3) maximum phytoplankton growth in the mid-salinity plume region, attributed to high nutrient concentrations and a nearoptimal light environment; and (4) a far-field plume region where phytoplankton growth rate is lower because river nutrients have been depleted.

The community structure and biomass of phytoplankton in any part of the system is dependent on complex interactions between growth rates of various phytoplankton species, mixing (dilution) rates between plume and oceanic waters, and loss factors associated primarily with grazing as well as direct aggregation and sinking. Data indicate that during the transition from the river to the oligotrophic open ocean system, the phytoplankton community structure shifts from a diatom dominated one, typical of a high nitrate, new nitrogen system (Bode \& Dortch 1996), to a picoplankton dominated one, typical of a low nitrate, recycling system (Liu et al. 2003).

Limited information from the Mississippi River plume suggests the contribution of grazing from microand mesozooplankton to the observed changes in phytoplankton biomass and community structure can be significant. Within the mid-salinity region of the plume, Fahnenstiel et al. (1995) reported that microzooplankton grazing rates on cells $<20 \mu \mathrm{m}$ averaged $82 \%$ of algal growth rates in the summer, although no grazing was observed on cells $>20 \mu \mathrm{m}$. Under far-field conditions slightly farther to the west, phytoplankton growth rates were nutrient-limited (Strom \& Strom 1996) and the microzooplankton grazing to phytoplankton growth ratio was typically between 0.3 and 0.9. In contrast to Fahnenstiel et al. (1995), Strom \& Strom (1996) observed significant consumption of large diatoms by microzooplankton (heterotrophic dinoflagellates) at some stations. It appears that a large fraction of the river nitrate incorporated into nanophytoplankton, and a smaller fraction of nitrate incorporated into larger phytoplankton, are grazed by microzooplankton. Mesozooplankton grazing can also be significant in this system. High concentrations of the larvacean Oikopleura dioica are commonly found in the vicinity of the Mississippi River plume (Dagg 1995, Dagg et al. 1996) and during May 1992, an estimated $20 \%$ of the upper $5 \mathrm{~m}$ was filtered daily by this species at stations within this area (Dagg et al. 1996). In a separate study, it was determined that between 4 and $62 \%$ of the daily algal production was consumed by the copepod community in plume waters during spring and fall (Dagg 1995). O. dioica feeds only on particles $<20 \mu \mathrm{m}$ (Alldredge \& Madin 1982, Flood et al. 1992, Bedo et al. 1993), whereas copepods generally are inefficient grazers of particles $<3$ to $5 \mu \mathrm{m}$ (e.g. Nival \& Nival 1976, Frost et al. 1983, Turner \& Tester 1989), but are more efficient with larger particles, including protozoans and other microzooplankton.

The grazing contribution of each component of the zooplankton community should vary spatially within the plume because the population response rate of each is quite different. The microzooplankton, particularly the smaller components, generally respond on approximately the same time-scale as their phytoplankton prey, suggesting grazing and growth within this portion of the food web should be closely coupled. In contrast, the population response rate of the mesozooplankton is considerably slower than their phytoplankton prey, suggesting a greater potential for imbalance between prey growth and mortality. It is apparent that relationships between light, nitrate availability, growth rate and grazing mortality will differ for different components of the phytoplankton community as well as in different portions of the plume system. The difficulty of understanding these trophic relationships is compounded by the highly variable and complex physical structure of the plume.

In this study, we examine micro- and mesozooplankton grazing on different size fractions of the phytoplankton community in several parts of the Mississippi River plume.

\section{MATERIALS AND METHODS}

Experiments measuring phytoplankton mortality due to micro- and mesozooplankton grazing were conducted in the Mississippi River plume during March 2002 (Fig. 1). Each experiment included 2 subexperiments: (1) A measurement of phytoplankton growth and microzooplankton grazing using the dilution technique (Landry \& Hasset 1982); and (2) a measurement of mesozooplankton grazing by the mesozooplankton addition approach (Calbet \& Landry 1999).

Prior to the cruise, all experimental bottles, tubing and other experimental materials were soaked for more than $24 \mathrm{~h}$ in Micro detergent, $10 \% \mathrm{HCl}$ and distilled and de-ionized water, respectively, followed by thorough rinsing with milli-Q water after each treatment. Experimental materials were also washed with $10 \% \mathrm{HCl}$ and rinsed with milli-Q water between each use on board. 


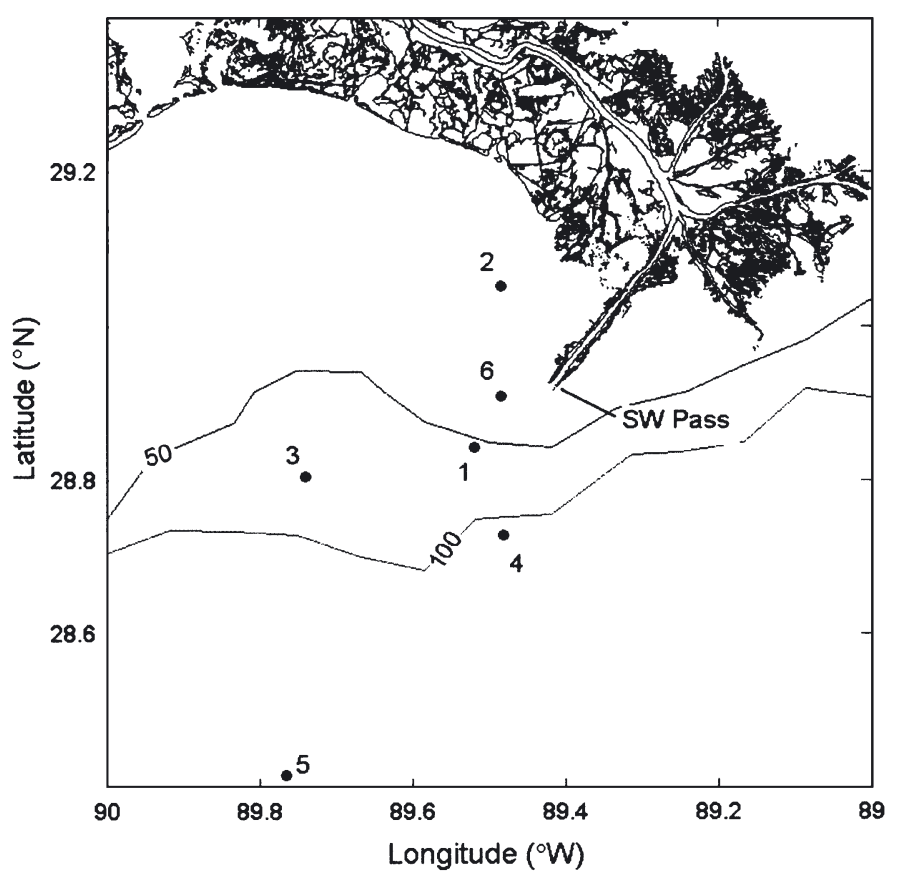

Fig. 1. Station locations. Contour depths in meters

For each experiment, seawater was collected from the surface $(<2 \mathrm{~m})$ with Niskin bottles. One 201 carboy was filled with seawater that was then gravity filtered with an in-line $(0.2 \mu \mathrm{m})$ filter capsule (previously acid soaked and thoroughly rinsed with seawater) into a clean polycarbonate carboy and used as the dilution medium. A 501 carboy was gently filled with $202 \mu \mathrm{m}$ screened water to be used as whole water. Replicate dilution treatments of $0.10,0.25,0.50,0.75$ and $1.0 \times$ natural seawater were prepared in 2.31 polycarbonate bottles. Nutrients $(10 \mu \mathrm{M}$ nitrate, $10 \mu \mathrm{M}$ silicate and $1 \mu \mathrm{M}$ phosphate, final concentration) were added to each bottle to promote constant growth of phytoplankton. Two bottles were filled with undiluted natural seawater without added nutrients to provide a control for the effects of nutrient enrichment on phytoplankton growth.

Mesozooplankton was collected by a 3 min tow in the upper $10 \mathrm{~m}$ using a $202 \mu \mathrm{m}$ mesh plankton net fitted with a General Oceanics flow meter to determine the volume of water filtered. Cod-end contents were carefully poured into an insulated container. Only freeswimming and healthy organisms that passed upwards through a submerged $2000 \mu \mathrm{m}$ mesh sieve were used in the experiments. Experimental bottles were filled with $200 \mu \mathrm{m}$ screened seawater and duplicate bottles containing 3 different concentrations of added mesozooplankton were prepared for each experiment. A nutrient mixture identical to that used in the dilution component was added to each bottle. Control bottles without animals were the same ones as in dilution experiments. Separate aliquots of mesozooplankton were filtered through a pre-weighed $20 \mu \mathrm{m}$ polycarbonate filter and dried in a $60^{\circ} \mathrm{C}$ oven for the determination of mesozooplankton dry weight. The remainder of the mesozooplankton sample was preserved with $10 \%$ buffered formalin for future identification and enumeration.

All experimental bottles were tightly capped and placed in on-deck incubators for $24 \mathrm{~h}$, with the temperature controlled by flowing surface seawater. One layer of neutral screen was applied to reduce the light level to about $50 \%$ surface irradiance. The chlorophyll a ( $\mathrm{chl}$ a) concentration in 3 size classes $(<5,5$ to 20 and $>20 \mu \mathrm{m}$ ) was determined in triplicate for the initial whole water, and in duplicate for each bottle at the end of incubation by filtering each sample through a $20 \mu \mathrm{m}$ polycarbonate filter, a $5 \mu \mathrm{m}$ polycarbonate filter and a GF/F glass fiber filter using a cascading filtration tower. Filters were extracted in $90 \%$ acetone for $24 \mathrm{~h}$ at $-20^{\circ} \mathrm{C}$ and the extract was measured with a Turner Design fluorometer to determine chl a concentrations (Strickland \& Parsons 1972).

For each experiment, the phytoplankton growth rate under nutrient-enriched conditions $\left(\mu_{n}\right)$ and phytoplankton mortality due to microzooplankton grazing $(m)$ were obtained by linear regression of apparent growth rate $\left(k_{\mathrm{n}} D\right)$ against dilution factor $(D$, fraction of undiluted seawater) from the nutrient-enriched dilution treatments. An estimate of the phytoplankton growth rate in water without added nutrients $\left(\mu_{0}\right)$ was calculated by:

$$
\mu_{0}=k_{0}+m
$$

where $k_{0}$ is the apparent growth rate of phytoplankton in the bottles that contained unamended natural seawater. When possible saturation grazing occurred (Gallegos 1989), only $k_{\mathrm{n}} D$ from greatly diluted treatments $(D<0.5)$ were used in the linear regression to obtain $\mu_{\mathrm{n}}$ (Redden et al. 2002). Consequently, $m$ was calculated from:

$$
m=\mu_{\mathrm{n}}-k_{\mathrm{n}}
$$

where $k_{\mathrm{n}}$ is the apparent growth rate in nutrientenriched whole seawater bottles.

Mesozooplankton grazing was determined by extrapolating the relationship between grazer biomass (mg dry wt $\mathrm{l}^{-1}$ ) and net growth rate of phytoplankton back to the in situ mesozooplankton biomass. In this study, the in situ mesozooplankton grazing rate on phytoplankton was calculated only for the $>20 \mu \mathrm{m}$ phytoplankton.

We refer to the 3 size fractions of phytoplankton as ultra- $(<5 \mu \mathrm{m})$, nano- (5 to $20 \mu \mathrm{m})$ and micro- $(>20 \mu \mathrm{m})$ phytoplankton, respectively. 


\section{RESULTS}

\section{Environmental conditions and plankton abundances}

Surface water temperature at our 6 experimental sites ranged only between 18.1 and $20.4^{\circ} \mathrm{C}$ and salinity varied between 23.80 and 33.62 (Table 1). Nitrate concentrations varied widely, being highest (approximately $37 \mu \mathrm{M})$ at Stn 6 close to the river mouth and lowest $(<1 \mu \mathrm{M})$ at Stns 4 and 5 (Table 1).

Chl a concentration at our experimental sites ranged from 3.6 to $10.0 \mathrm{mg} \mathrm{m}^{-3}$ (Table 1). At all stations, chl a was dominated by phytoplankton cells in the $>20 \mu \mathrm{m}$ and/or 5 to $20 \mu \mathrm{m}$ size fractions (Table 1 ). The relatively high chl a concentration and the dominance of large phytoplankton indicate that none of the stations were located in truly oligotrophic waters representative of the open Gulf of Mexico, where surface salinities are typically $>36$ and chl a concentrations are $<1.0 \mathrm{mg} \mathrm{m}^{-3}$.

Mesozooplankton abundance and biomass in the upper $10 \mathrm{~m}$ varied widely (Tables 1 \& 2). The lowest abundance and biomass occurred at Stn 2 in the shallow coastal water north of the river mouth where Acartia tonsa and other neritic copepods dominated. The highest abundance and biomass were observed at Stn 4 where zooplankton species composition was more diverse and a large amount of gelatinous zooplankton (doliolids and larvaceans) was observed.

Based on these properties, we consider Stns 1 and 6 as near-field stations, Stn 5 as a far-field station, and Stns 3 and 4 as intermediate between these conditions. Stn 2, located in a region where river water often accumulates (Wiseman et al. 1982), has salinity and nitrate properties that link it to near-field Stn 6, but this river water is probably considerably older and not in the river plume proper.

\section{Phytoplankton growth and microzooplankton grazing}

All 6 dilution experiments produced statistically significant estimates of phytoplankton growth and microzooplankton grazing rates in all 3 size fractions of phytoplankton (Table 3, Fig. 2). At all stations in the near- and mid-field locations (i.e. all stations except Stn 5), phytoplankton grew rapidly during our study period. At these stations, in situ growth rates $\left(\mu_{0}\right)$ were usually higher than 1 doubling per day in all 3 sizefractions (Table 3). The highest in situ growth rates of more than 2 doublings per day were found in the $>20 \mu \mathrm{m}$ fraction at Stns 1 and 6, near the river discharge site at Southwest Pass. In all 3 size fractions, growth rates were lowest at the far-field, Stn 5 .

Microzooplankton grazing rates were much lower than phytoplankton growth rates in all 3 size fractions at Stns 1 and 6, located close to the river mouth. At the mid-field, Stns 3 and 4, grazing rates were not consistently higher or lower than growth rates in all size categories. At the far-field, Stn 5, the grazing rate was low, but still greatly exceeded the phytoplankton growth rate $\left(\mu_{0}\right)$ in all 3 size categories (Table 3 ). Overall, phytoplankton growth rates in all 3 size fractions were between 0.5 and $1.5 \mathrm{~d}^{-1}$ in waters with salinity $<31$, but were much lower at the far-field station $\left(<0.2 \mathrm{~d}^{-1}\right)$ (Fig. 3a). Microzooplankton grazing rates, however, were low at the lowest salinities, peaked at mid-salinities and declined again at highest salinities (Fig. 3b).

The ratio of in situ phytoplankton growth to growth in the nutrient-enriched treatments, $\mu_{0} / \mu_{\mathrm{n}}$, is an indication of the degree of nutrient-limitation. When plotted against salinity (Fig. 3c), the ratio of $\mu_{0} / \mu_{\mathrm{n}}$ declined as salinity increased above 30 . The $\mu_{0} / \mu_{\mathrm{n}}$ ratio in experiments conducted at salinity $<30$ was near 1 , indicating no nutrient limitation occurred at the near-field Stns 1 and 6. At the mid-field Stns 3 and 4, the ratio was approximately 0.5 and at the far-field Stn 5, the lowest ratio was observed, approximately 0.3 . At salinities > 30 , the ratio decreased with increasing salinity, especially in the microphytoplankton (>20 $\mu \mathrm{m}$ category), suggesting nutrients become increasingly limiting as the plume water moves from the near-field to the farfield. The growth-grazing index $\left[\left(\mu_{0}-m\right) / \mu_{0}\right]$ was generally positive at salinities $<30$ (Fig. 3d), indicating that growth surpassed grazing, but was generally negative at salinity $>30$, indicating that grazing exceeded

Table 1. Summary of locations, hydrographic conditions, nutrient concentrations, initial chl a concentrations and in situ mesozooplankton biomass of each grazing experiment

\begin{tabular}{|c|c|c|c|c|c|c|c|c|c|c|c|c|c|}
\hline Stn & Date & $\begin{array}{l}\text { Lat. } \\
\left({ }^{\circ} \mathrm{N}\right)\end{array}$ & $\begin{array}{l}\text { Long. } \\
\left({ }^{\circ} \mathrm{W}\right)\end{array}$ & $\begin{array}{l}\text { Temp. } \\
\left({ }^{\circ} \mathrm{C}\right)\end{array}$ & Salinity & $\begin{array}{r}\text { Nitrate } \\
(\mu \mathrm{M})\end{array}$ & $\begin{array}{c}\text { Phosphate } \\
(\mu \mathrm{M})\end{array}$ & $\begin{array}{c}\text { Silicate } \\
(\mu \mathrm{M})\end{array}$ & $<5 \mu \mathrm{m}$ & $\begin{array}{l}\text { Chl a (m } \\
5-20 \mu \mathrm{m}\end{array}$ & $\begin{array}{l}\left.\lg \mathrm{m}^{-3}\right) \\
>20 \mu \mathrm{m}\end{array}$ & Total & $\begin{array}{c}\text { Biomass } \\
\left(\mathrm{mg} \text { dry wt } \mathrm{m}^{-3}\right)\end{array}$ \\
\hline 1 & Mar/13 & 28.843 & 89.518 & 18.10 & 28.75 & 4.94 & 0.41 & 7.06 & 0.84 & 2.80 & 1.75 & 5.39 & 83.3 \\
\hline 2 & Mar/17 & 29.054 & 89.483 & 18.86 & 25.50 & 8.08 & 0.58 & 24.75 & 0.84 & 4.95 & 4.25 & 10.04 & 2.8 \\
\hline 3 & Mar/18 & 28.805 & 89.738 & 19.35 & 30.15 & 0.92 & 0.62 & 3.08 & 0.34 & 1.64 & 3.66 & 5.64 & 16.7 \\
\hline 4 & Mar/20 & 28.730 & 89.481 & 19.90 & 30.10 & $<0.075$ & 0.07 & 0.86 & 0.42 & 1.44 & 2.95 & 4.82 & 104.7 \\
\hline 5 & Mar/23 & 28.416 & 89.764 & 20.40 & 33.62 & 0.30 & 0.09 & 0.71 & 0.44 & 0.79 & 3.09 & 4.33 & 57.4 \\
\hline 6 & Mar/24 & 28.910 & 89.485 & 17.50 & 23.80 & 37.01 & 0.20 & 31.63 & 0.45 & 1.47 & 1.65 & 3.57 & 29.6 \\
\hline
\end{tabular}


Table 2. Mesozooplankton abundance and dominant zooplankton species (groups) at the site of each grazing experiment. Species (groups) that account for more than $3 \%$ of the total mesozooplankton abundance were listed

\begin{tabular}{|c|c|c|c|}
\hline Stn & $\begin{array}{l}\text { Mesozooplank- } \\
\text { ton (ind. } \mathrm{m}^{-3} \text { ) }\end{array}$ & $\begin{array}{l}\text { Dominant copepods } \\
(\%)\end{array}$ & $\begin{array}{l}\text { Other dominant } \\
\text { zooplankton }(\%)\end{array}$ \\
\hline 1 & 3298 & $\begin{array}{l}\text { Acartia tonsa (30.6) } \\
\text { Paracalanus spp. }(26.3) \\
\text { Subeucalanus spp. }(4.4) \\
\text { Corycaeus spp. (4.0) }\end{array}$ & $\begin{array}{l}\text { Doliolids (5.6) } \\
\text { Misc. eggs (4.8) }\end{array}$ \\
\hline 2 & 1474 & $\begin{array}{l}\text { Acartia tonsa (87.4) } \\
\text { Paracalanus crassirostris (8.0) }\end{array}$ & \\
\hline 3 & 3343 & $\begin{array}{l}\text { Acartia tonsa (31.3) } \\
\text { Paracalanus spp. (19.5) } \\
\text { Paracalanus crassirostris (13.5) } \\
\text { Oncaea spp. (3.6) } \\
\text { Euterpina spp. (3.6) } \\
\text { Subeucalanus spp. (3.4) } \\
\text { Corycaeus spp. (3.4) }\end{array}$ & Larvacean (7.0) \\
\hline 4 & 8302 & $\begin{array}{l}\text { Acartia tonsa (23.0) } \\
\text { Paracalanus spp. }(19.7) \\
\text { Paracalanus crassirostris (6.6) } \\
\text { Corycaeus spp. }(3.9) \\
\text { Labidocera spp. }(3.3)\end{array}$ & $\begin{array}{l}\text { Doliolids (9.6) } \\
\text { Misc. eggs }(7.7) \\
\text { Larvacean (5.2) } \\
\text { Nauplii }(5.2)\end{array}$ \\
\hline 5 & 2080 & $\begin{array}{l}\text { Paracalanus spp. (17.5) } \\
\text { Acartia tonsa (13.2) } \\
\text { Oncaea spp. }(12.0) \\
\text { Corycaeus spp. }(3.8) \\
\text { Nannocalanus minor }(3.2)\end{array}$ & $\begin{array}{l}\text { Doliolids (18.6) } \\
\text { Nauplii (3.0) }\end{array}$ \\
\hline 6 & 4609 & Acartia tonsa (79.2) & Larvacean (4.1) \\
\hline
\end{tabular}

\section{Mesozooplankton grazing}

In all experiments, the net growth rate of the $>20 \mu \mathrm{m}$ phytoplankton decreased with increasing concentration of mesozooplankton (Fig. 4). The impacts of mesozooplankton grazing on the 3 phytoplankton size fractions, normalized to mesozooplankton dry weight, are shown in Table 5. Direct consumption of $>20 \mu \mathrm{m}$ phytoplankton by mesozooplankton is apparent in all experiments. In the 5-20 $\mu \mathrm{m}$ size fraction, there appeared to be some direct consumption by mesozooplankton at the near-field Stns 1 and 6, although the slopes of these lines (the decrease in net growth rate per unit of additional mesozooplankton biomass) were smaller than those seen in the $>20 \mu \mathrm{m}$ category. In the transition Stns 3 and 4, there did not appear to be any net effect of mesozooplankton on growth of the 5-20 $\mu \mathrm{m}$ size category. At the far-field Stn 5, there was an increase in the net growth of phytoplankton in the 5-20 $\mu \mathrm{m}$ category with increasing mesozooplankton concentration. In the smallest size phytoplankton category,

growth (Fig. 3d). This index was strongly negative at the far-field Stn 5.

In some experiments, especially in the nano- and micro-fractions, there was evidence of saturated grazing (Fig. 2). Growth rates calculated only from bottles with dilution factors $<0.5$, and grazing rates calculated from Eq. (2), are slightly higher than rates estimated by the full linear regression (Table 4). Nutrient-enriched growth rates estimated from this approach are on average $19.8 \%$ (range 5 to $46 \%$ ) and $8.7 \%$ (4 to $21 \%$ ) higher than rates estimated by the full linear regression for nano- and micro-phytoplankton, respectively. For grazing rates, the differences are $10.6 \%$ (3 to $24 \%$ ) and $6.1 \%$ (3 to $16 \%$ ), respectively. $<5 \mu \mathrm{m}$, there was a slight decrease in net growth rate with mesozooplankton biomass increase at the near-field stations and an enhancement of net phytoplankton growth with increasing mesozooplankton concentration at the transition and far-field stations.

At Stns 4, $5 \&$ \&, we examined the possibility that large phytoplankton might be concentrated and collected in the zooplankton net haul and then added to the incubation bottles with the experimental mesozooplankton grazers. This would increase the initial concentration of chl a in the experimental bottles over that in the control bottles, which had no mesozooplankton additions, resulting in an underestimation of the final grazing rate. At Stns 4, 5 \& 6, we measured the chl a

Table 3. Summary of size fractionated phytoplankton growth and microzooplankton grazing rates $\left(\mathrm{d}^{-1}\right)$ measured by dilution technique. $\mu_{\mathrm{n}}=$ growth rate from regression analyses of bottles incubated with added nutrients; $\mu_{0}=$ growth rate without added nutrients; $m=$ microzooplankton grazing rate; $\mathrm{r}^{2}=$ correlation coefficient of regression analysis

\begin{tabular}{|c|c|c|c|c|c|c|c|c|c|c|c|c|}
\hline \multirow[t]{2}{*}{ Stn } & \multicolumn{4}{|c|}{$<5 \mu \mathrm{m}$} & \multicolumn{4}{|c|}{$5-20 \mu \mathrm{m}$} & \multicolumn{4}{|c|}{$>20 \mu \mathrm{m}$} \\
\hline & $\mu_{\mathrm{n}}$ & $\mu_{0}$ & $m$ & $\mathrm{r}^{2}$ & $\mu_{\mathrm{n}}$ & $\mu_{0}$ & $m$ & $\mathrm{r}^{2}$ & $\mu_{\mathrm{n}}$ & $\mu_{0}$ & $m$ & $\mathrm{r}^{2}$ \\
\hline 1 & 0.88 & 0.80 & 0.48 & 0.71 & 0.58 & 0.70 & 0.53 & 0.57 & 1.53 & 1.54 & 0.41 & 0.66 \\
\hline 2 & 1.36 & 1.07 & 0.50 & 0.61 & 0.84 & 0.82 & 0.93 & 0.86 & 1.30 & 0.87 & 0.50 & 0.87 \\
\hline 3 & 1.33 & 0.81 & 1.09 & 0.80 & 1.21 & 0.62 & 1.82 & 0.96 & 2.14 & 1.25 & 1.26 & 0.95 \\
\hline 4 & 1.40 & 1.08 & 0.97 & 0.92 & 1.66 & 0.85 & 0.97 & 0.87 & 2.23 & 1.04 & 0.70 & 0.75 \\
\hline 5 & 0.30 & 0.09 & 0.75 & 0.85 & 0.37 & -0.05 & 0.34 & 0.31 & 0.73 & 0.18 & 0.37 & 0.31 \\
\hline 6 & 0.77 & 0.80 & 0.18 & 0.38 & 0.42 & 0.44 & 0.17 & 0.30 & 1.53 & 1.60 & 0.50 & 0.80 \\
\hline
\end{tabular}



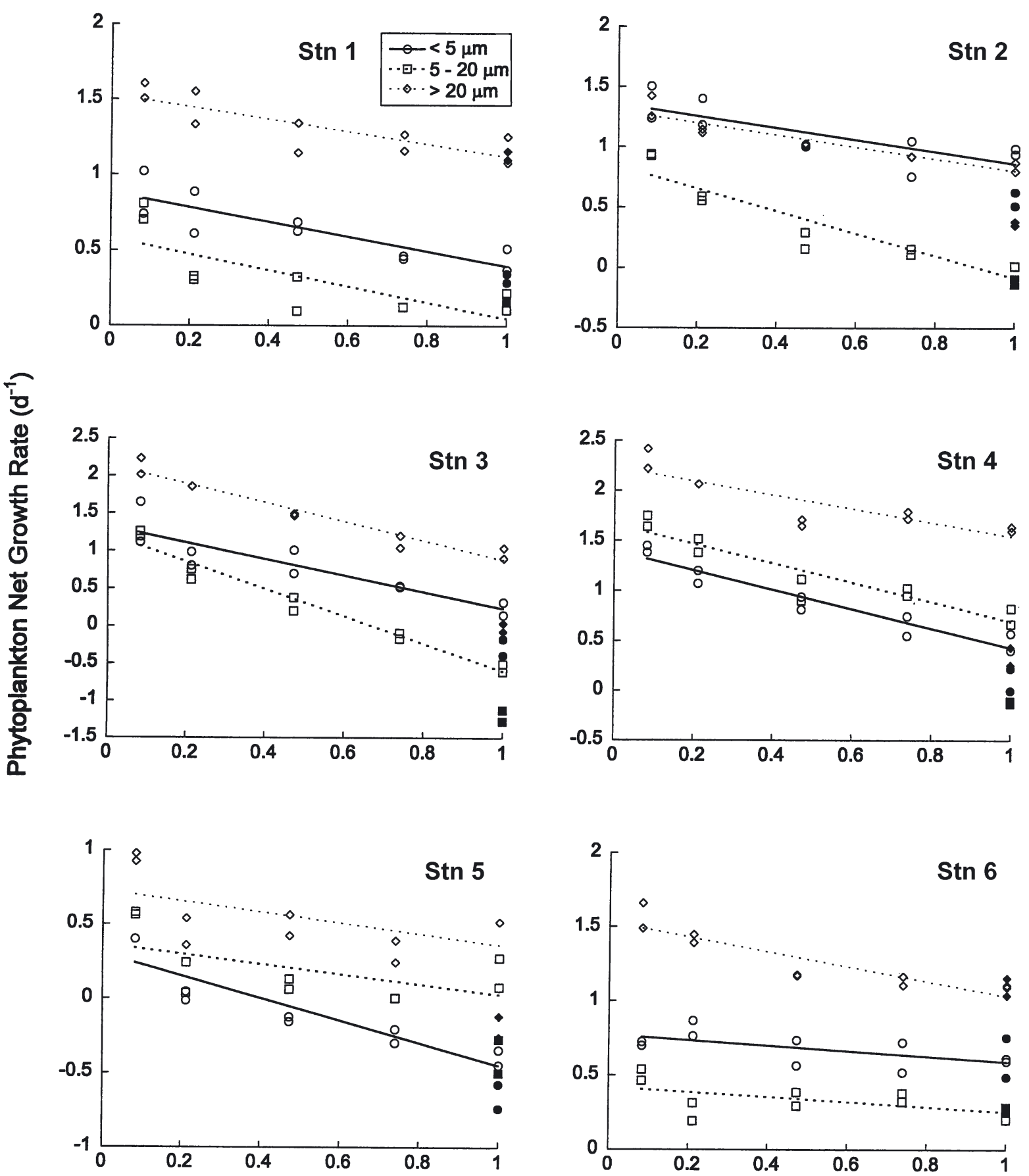

Fraction Undiluted Seawater

Fig. 2. Dilution experiments. Net growth of phytoplankton in 3 size categories plotted against the fraction of unfiltered seawater. Lines are least-squared fits by linear regression

content of a mesozooplankton aliquot identical to that added to each experimental bottle. Results indicated we had underestimated grazing on the $>20 \mu \mathrm{m}$ size category by $7.2,63.5$ and $25.5 \%$ at Stns $4,5 \& 6$ respectively (Table 4). The greatest underestimation occurred at Stn 5, where high abundance of doliolids might have clogged the net, increasing the amount of phytoplankton collected. Because we cannot determine the degree of underestimation in our other experiments, we have not attempted corrections. 

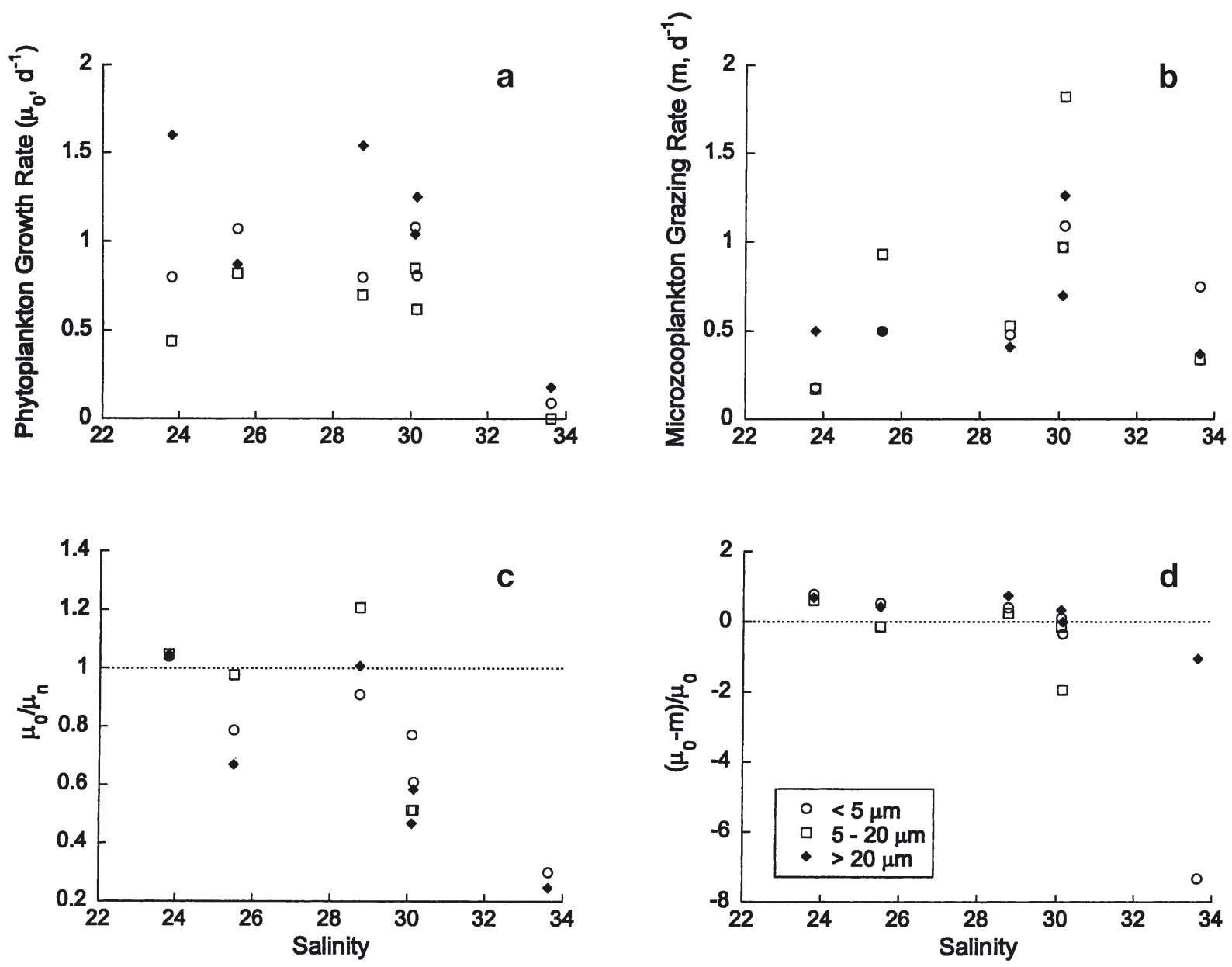

Fig. 3. Relationships between salinity and (a) phytoplankton growth rate $\left(\mu_{0}\right)$, (b) microzooplankton grazing rate $(m)$, (c) nutrient limitation index $\left(\mu_{0} / \mu_{\mathrm{n}}\right)$ and (d) growth-grazing index $\left[\left(\mu_{0}-m\right) / \mu_{0}\right]$. A $\mu_{0} / \mu_{\mathrm{n}}$ of 1 indicates no nutrient limitation and a value of less than 1 indicates nutrient limitation occurred during incubation. A positive growth-grazing index means phytoplankton growth exceeds grazing losses

The in situ grazing by mesozooplankton was determined by inserting the mesozooplankton biomass at each station into the regression equation derived from that station (Fig. 4). In situ mesozooplankton grazing on the $>20 \mu \mathrm{m}$ fraction of the phytoplankton community ranged from $<1 \%$ of daily growth at near-field Stn 6 , with slightly higher consumption $(4.9 \%$ daily growth) at near-field Stn 1. At transition Stns 3 and 4, consumption was 0.1 and $9.8 \%$ of growth of $>20 \mu \mathrm{m}$ cells, whereas at the far-field Stn 5, mesozooplankton consumption of large cells was equivalent to $86.5 \%$ of daily growth (Table 6).

\section{DISCUSSION}

Like many large river systems, salinity and chl a concentration are low and nitrate concentration is high near the mouth of the Mississippi River. As plume waters move from near- to far-field, salinity increases due to mixing with oceanic waters, nitrate decreases due to phytoplankton growth, and phytoplankton biomass (chl a) increases. In the Mississippi River plume,

Table 4. Comparison of nano- and microphytoplankton growth rates $\left(\mu_{\mathrm{n}}, \mathrm{d}^{-1}\right)$ and microzooplankton grazing rates $(m$, $\mathrm{d}^{-1}$ ) calculated from the whole dilution series of nutrientenriched incubation and from only highly diluted $(D<0.5)$ samples

\begin{tabular}{|ccccccccccc|}
\hline \multirow{3}{*}{ Stn } & \multicolumn{4}{c}{$5-20 \mu \mathrm{m}$} & \multicolumn{4}{c|}{$>20 \mu \mathrm{m}$} \\
& \multicolumn{3}{c}{ Whole } & \multicolumn{2}{c}{$D<0.5$} & \multicolumn{2}{c|}{ Whole } & \multicolumn{2}{c|}{$D<0.5$} \\
\multicolumn{4}{c}{ dilution } & \multicolumn{2}{c}{ only } & \multicolumn{2}{c}{ dilution } & \multicolumn{2}{c}{ only } \\
& $\mu_{\mathrm{n}}$ & $m$ & $\mu_{\mathrm{n}}$ & $m$ & & $\mu_{\mathrm{n}}$ & $m$ & $\mu_{\mathrm{n}}$ & $m$ \\
\hline 1 & 0.58 & 0.53 & 0.75 & 0.58 & 1.53 & 0.41 & 1.62 & 0.45 \\
2 & 0.84 & 0.93 & 1.02 & 1.00 & 1.30 & 0.50 & 1.36 & 0.52 \\
3 & 1.21 & 1.82 & 1.31 & 1.87 & 2.14 & 1.26 & 2.23 & 1.26 \\
4 & 1.66 & 0.97 & 1.83 & 1.08 & 2.23 & 0.70 & 2.43 & 0.81 \\
5 & 0.37 & 0.34 & 0.54 & 0.37 & 0.73 & 0.37 & 0.88 & 0.36 \\
6 & 0.42 & 0.17 & 0.44 & 0.21 & 1.53 & 0.50 & 1.65 & 0.55 \\
\hline
\end{tabular}



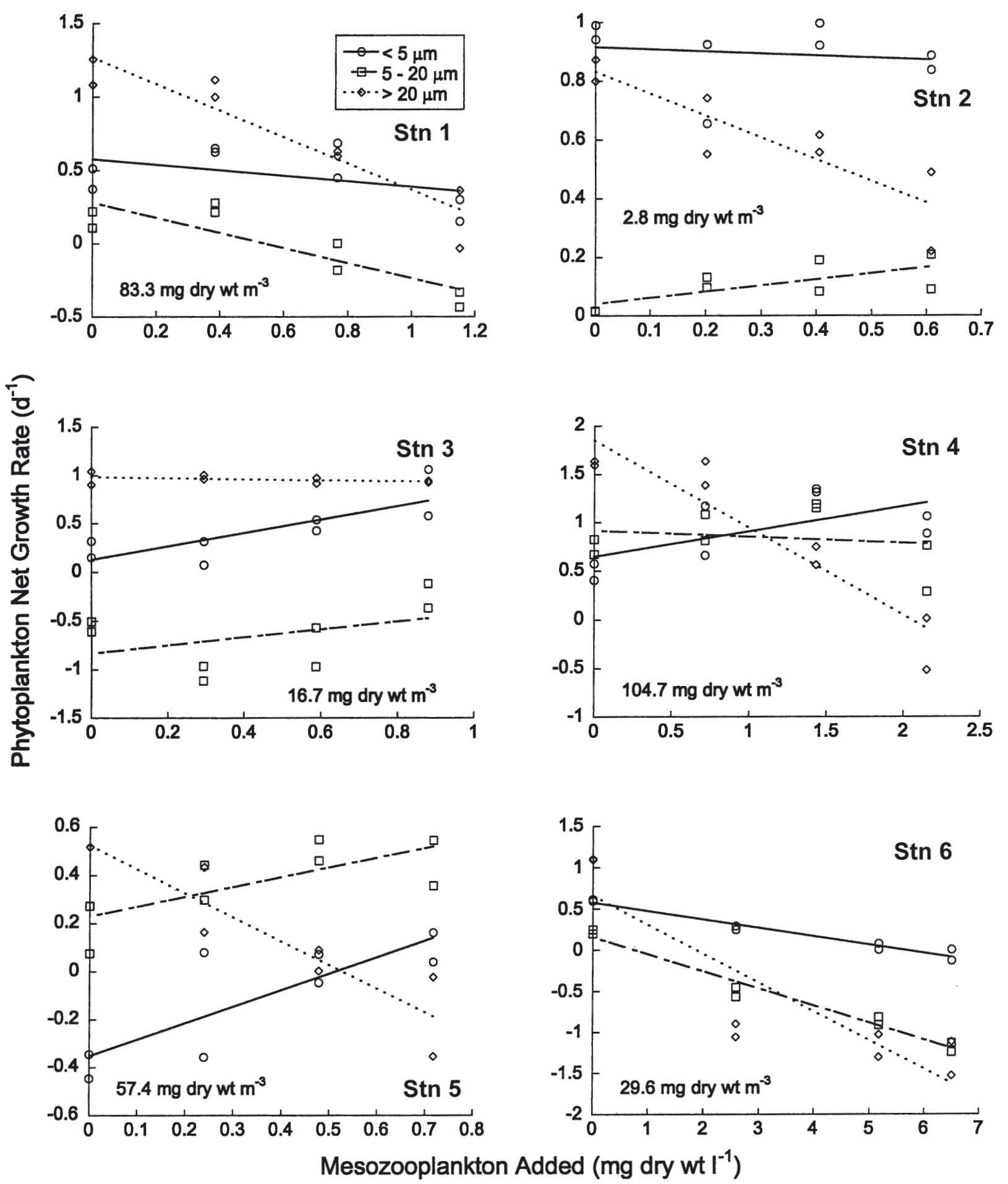

Fig. 4. Effects of mesozooplankton biomass (mg dry $\mathrm{wt}^{-1}$ ) on net growth rates of 3 phytoplankton size fractions. Lines are least-squared fits by linear regression. In situ mesozooplankton biomass at each experimental site is also given

a chl a maximum is typically observed at mid-salinity locations (Lohrenz et al. 1999). Farther afield at high salinity locations, nitrate becomes depleted, phytoplankton growth slows and chl a declines. Eventually the river water will acquire the characteristics of the oligotrophic open Gulf of Mexico and become dominated by a microbial food web. In this system, transit time from near- to far-field is probably in the order of a 
Table 5. Mesozooplankton grazing impact (change in net growth rate of phytoplankton $\left[\mathrm{d}^{-1}\right]$ per mg dry wt $\mathrm{l}^{-1}$ increase in mesozooplankton biomass, $\mathrm{d}^{-1}\left[\mathrm{mg} \text { dry } \mathrm{wt}^{-1}\right]^{-1}$ ) estimated from the slope of linear regressions displayed in Fig. 4. A negative slope indicates a decrease in net growth rate and a positive slope indicates an increase in net growth of phytoplankton during incubation with added mesozooplankton. For the $>20 \mu \mathrm{m}$ size fraction, the 'corrected' column accounts for the added net-caught phytoplankton to the incubation bottles with the mesozooplankton additions. ns - not significant; ${ }^{*} \mathrm{p}<0.05,{ }^{* *} \mathrm{p}<0.01,{ }^{* * *} \mathrm{p}<0.001$

\begin{tabular}{|c|c|c|c|c|c|c|c|c|c|c|c|c|}
\hline \multirow[t]{2}{*}{ Stn } & \multicolumn{3}{|c|}{$<5 \mu \mathrm{m}$} & \multicolumn{3}{|c|}{$5-20 \mu \mathrm{m}$} & \multicolumn{3}{|c|}{$>20 \mu \mathrm{m}$} & \multicolumn{3}{|c|}{$>20 \mu \mathrm{m}$ (corrected) } \\
\hline & Slope & $r^{2}$ & $\mathrm{p}$ & Slope & $\mathrm{r}^{2}$ & $\mathrm{p}$ & Slope & $\mathrm{r}^{2}$ & $\mathrm{p}$ & Slope & $\mathrm{r}^{2}$ & $\mathrm{p}$ \\
\hline 1 & -0.189 & 0.21 & ns & -0.515 & 0.76 & ** & -0.900 & 0.88 & $* * *$ & & & \\
\hline 2 & -0.072 & 0.03 & $\mathrm{~ns}$ & 0.209 & 0.51 & ${ }^{*}$ & -0.743 & 0.77 & $* *$ & & & \\
\hline 3 & 0.693 & 0.63 & $*$ & 0.412 & 0.18 & $\mathrm{~ns}$ & -0.054 & 0.16 & $\mathrm{~ns}$ & & & \\
\hline 4 & 0.260 & 0.40 & $\mathrm{~ns}$ & -0.064 & 0.03 & $\mathrm{~ns}$ & -0.901 & 0.88 & $* * *$ & -0.973 & 0.90 & $* * *$ \\
\hline 5 & 0.688 & 0.68 & $*$ & 0.402 & 0.52 & $*$ & -0.991 & 0.85 & $* * *$ & -2.711 & 0.84 & $* *$ \\
\hline 6 & -0.102 & 0.96 & $* * *$ & -0.208 & 0.97 & $* * *$ & -0.351 & 0.78 & $* *$ & -0.471 & 0.80 & $* *$ \\
\hline
\end{tabular}

few days. For example, a drifter study done during high discharge showed transit of drifters within the plume over distances greater than our study area occurred in approximately $48 \mathrm{~h}$ (Hitchcock et al. 1997).

In our study, station characteristics of salinity, nitrate concentration and chl a concentration were generally consistent with this conceptual model. Stns 1 and 6 had near-field characteristics, and Stn 5 was a far-field station. Stns 3 and 4 were intermediate or transition stations. Stn 2, to the north of Southwest Pass, did not fit this pattern and appeared to be composed of older water that was outside of the plume. Water in this region tends to accumulate as part of a large eddy formed by a mixture of river and shelf waters (Wiseman et al. 1982). All characteristics, however, did not fit completely in our conceptual model, especially when more detailed analyses of the biological properties and rates were examined. For example, we did not see a microbial web type of community at our far-field station. Instead, chl a concentration was still quite high at our Stn 5 and large phytoplankton still dominated the phytoplankton community. Indications were, however, that this was to be short-lived because growth of all phytoplankton was greatly decreased at this station, and mortality from grazing, both via micro- and mesozooplankton, exceeded growth. Clearly, this phytoplankton community was being cropped back rapidly by grazers and, in the framework of our conceptual model, would soon take on the characteristics of a microbial food web.

Phytoplankton in all 3 size fractions grew rapidly at mid-field stations and the growth rate decreased toward open ocean waters. Except at the far-field station, phytoplankton growth rates were all higher than 1 doubling per day, with the growth rate of the $>20 \mu \mathrm{m}$ phytoplankton higher than 2 doublings per day at some stations. These rates are within the ranges of previous reports (Fahnenstiel et al. 1995, Strom \& Strom 1996) which also showed nutrient limitation of phytoplankton growth in the far-field or offshore sites, with diatoms the most severely affected.

Results from the present study add to the growing evidence that microzooplankton are important consumers of phytoplankton in communities dominated by large phytoplankton (e.g. Calbet 2001, Sherr \& Sherr 2002 and references therein). Diatoms accounted for most of the phytoplankton biomass at all experimental sites during this study (T. Bianchi pers. comm.), and we

Table 6. Estimates of the percentage of daily phytoplankton growth that was consumed by mesozooplankton (for $>20 \mu \mathrm{m}$ phytoplankton only) using mesozooplankton grazing rate estimated by bottle incubation experiments and mesozooplankton biomass at the sites of experiments

\begin{tabular}{|c|c|c|c|c|c|}
\hline Stn & $\begin{array}{l}\text { Phytoplankton } \\
\text { growth } \\
\left(\mathrm{d}^{-1}\right)\end{array}$ & 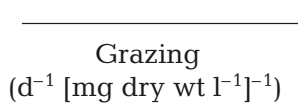 & $\begin{array}{c}\text { Mesozooplankton } \\
\text { Biomass } \\
\left(\mathrm{mg} \text { dry wt } \mathrm{m}^{-3} \text { ) }\right.\end{array}$ & $\begin{array}{l}\text { In situ grazing } \\
\qquad\left(\mathrm{d}^{-1}\right)\end{array}$ & $\begin{array}{l}\text { Phytoplankton } \\
\text { growth consumed } \\
\qquad\left(\% \mathrm{~d}^{-1}\right)\end{array}$ \\
\hline 1 & 1.54 & 0.900 & 83.3 & 0.075 & 4.9 \\
\hline 2 & 0.87 & 0.743 & 2.8 & 0.002 & 0.2 \\
\hline 3 & 1.25 & 0.054 & 16.7 & 0.001 & 0.1 \\
\hline 4 & 1.04 & 0.973 & 104.7 & 0.102 & 9.8 \\
\hline 5 & 0.18 & 2.711 & 57.4 & 0.156 & 86.5 \\
\hline 6 & 1.60 & 0.471 & 29.6 & 0.014 & 0.9 \\
\hline
\end{tabular}


observed significant microzooplankton grazing on all 3 size fractions of phytoplankton at all stations. Dinoflagellates that are able to feed on large chainforming diatoms through extracellular digestion (Gaines \& Taylor 1984) are the most likely microzooplankton consumers of diatoms. Strom \& Strom (1996) observed the ingestion of chain diatoms by the dinoflagellate Gyrodinium sp. in coastal waters of the northern Gulf of Mexico.

In mesotrophic to eutrophic systems, when phytoplankton concentration is sufficiently high, grazing can become saturated and thus be independent of phytoplankton concentration. Even at low in situ chl a concentrations $\left(<1 \mathrm{mg} \mathrm{m}^{-3}\right)$, there is evidence of grazing saturation in the northern Gulf of Mexico (Strom \& Strom 1996). Saturated grazing has been observed in many coastal waters and several approaches for interpreting data from dilution experiments have been proposed, ranging from simple empirical approximation to complex non-linear curve fitting (e.g. Gallegos 1989, Evans \& Paranjape 1992, Gallegos \& Jordan 1997, Redden et al. 2002). In our study, we observed saturated grazing in the nano- and micro-fractions in the majority of experiments, but no indication of saturated grazing was found in the ultra-fraction, cells $<5 \mu \mathrm{m}$ (Fig. 2). Possibly, microzooplankton grazers were better able to control the ultra-fraction of the phytoplankton community than the nano- and micro-fractions, thereby preventing accumulation of biomass in this component of the community, and thus reducing the possibility of feeding saturation. Many protists are believed to have the same growth potential as their microbial prey (e.g. Fenchel 1982, Muller \& Geller 1993, Sherr \& Sherr 1994 and references therein).

We found a wide range of mesozooplankton grazing rates in the relatively small region of our study area (Table 6). Our experiments suggest that mesozooplankton communities, particularly the crustacean components, are most important at the intermediateand far-field locations, because the numerical response of these organisms is slow compared to the phytoplankton growth rates (Dagg 1988, 1995). The impact of mesozooplankton on phytoplankton was low at near-field and intermediate-field locations and highest at our far-field station where more than $80 \%$ of daily growth of the $>20 \mu \mathrm{m}$ phytoplankton was consumed by mesozooplankton. These limited data indicate that only at the far-field station does mesozooplankton grazing contribute significantly in a direct manner to phytoplankton mortality and the development of the overall near- to far-field pattern of phytoplankton biomass.

Our mesozooplankton grazing rates are probably underestimates of the in situ impact of the mesozooplankton community on phytoplankton, because the impact of gelatinous mesozooplankton was largely unaccounted for. Gelatinous microphages, including larvaceans, salps and doliolids, are able to feed on a wide size range of particles (Flood et al. 1992, Fortier et al. 1994, Zeldis et al. 1995) and are frequently abundant in continental shelf waters of the northern Gulf of Mexico. Earlier work (Dagg 1995, Dagg et al. 1996) indicated that the larvacean Oikopleura dioica can be a major consumer of particles in the $<20 \mu \mathrm{m}$ size range. During this study, in March 2002, a large community of doliolids, composed almost entirely of Dolioletta gegenbauri, was present at the outer transition Stn 4 and the far-field Stn 5; however, our experiments did not include the grazing impact of this population, because these organisms were damaged during collection by plankton net. Separate experiments measuring the clearance rates of these delicate organisms are needed to obtain a more accurate estimate of their contribution to overall mesozooplankton grazing.

Mesozooplankton grazers may also contribute indirectly to the size structure of the phytoplankton community by cropping down microzooplankton. Microzooplankton can contribute significantly to the diet of mesozooplankton, even when large diatoms are abundant (Stoecker \& Capuzzo 1990, Gifford 1991, Froneman et al. 1996). In our mesozooplankton grazing experiments, phytoplankton in the $<5 \mu \mathrm{m}$ size category increased with increasing mesozooplankton concentration at intermediate- and far-field stations. This was also observed for cells in the 5 to $20 \mu \mathrm{m}$ category (except at Stn 4). We believe this is a cascade effect caused by mesozoplankton grazing on microzooplankton at these stations. The resultant reduction in microzooplankton grazing on the small- and intermediatesized cells allows them to increase during the incubation. We did not observe this at the near-field stations because, as indicated by the low microzooplankton grazing rates, microzooplankton abundance was low at those stations. While mesozooplankton grazing on ciliates can reduce the mortality rate on nano- and ultraphytoplankton, it can also lead to an increase in heterotrophic nanoflagellate abundance, and consequently to an increased mortality on ultraplankton (e.g. Calbet \& Landry 1999). The final result of the cascading effect caused by adding mesozooplankton to incubation bottles depends on the overall structure and the relative abundance of each component of the microbial food web. More experimental work is required to determine how food web structure and the relative abundance of phytoplankton and microzooplankton affect these trophic cascading processes.

The use of total chl a as a measure of mesozooplankton grazing could result in a significant underestimation of total ingestion when trophic cascading 
is occurring. Increases in small phytoplankton resulting from trophic cascading, such as we observed at intermediate- and far-field stations, would conceal part of mesozooplankton grazing if only total chl $a$ was measured. For example, at Stn 5, mesozooplankton grazing on the $>20 \mu \mathrm{m}$ size fraction was equivalent to $12.2 \%$ of the total chl a stock available, but without correcting for the increases in chl $a$ in the small size fractions, it would appear that only $4.9 \%$ of total chl a was ingested daily by mesozooplankton. To fully correct for cascading effects, a correction that quantifies the increase of phytoplankton growth rate resulting from the release of microzooplankton grazing must always be incorporated (Nejstgaard et al. 1997, 2001).

The dynamics between growth and grazing mortality in the different size fractions of the phytoplankton community, combined with varying growth rates associated with rapidly declining nutrient concentrations, and superimposed on a background of dilution derived from mixing of plume water with oligotrophic oceanic water, makes this system exceptionally complex. Nevertheless, these few experiments indicate that microzooplankton grazing rates were low in the near-field, highest in intermediate stations and then declined in the far-field. As the plume dispersed and mixed with higher salinity shelf water, inorganic nutrients become exhausted and phytoplankton growth (especially the large diatoms) become nutrient-limited. During this transition, microzooplankton grazing rate surpassed phytoplankton growth rate, causing a decline in phytoplankton biomass. Mesozooplankton grazing enhanced this decline by adding an additional grazing mortality, especially to the large phytoplankton cells. In this study, grazing mortality surpassed growth at a salinity of approximately 30, where nutrient limitation began to be important. During other times of the year, the region of this transition would likely be different because of variables such as temperature and river discharge. An extension of this pattern farther down-plume would result in a phytoplankton community of low biomass dominated by small cells, but since none of our stations were in truly oligotrophic conditions, we did not observe this. It is probable that these patterns apply to other continental shelves that are dominated by large rivers.

Acknowledgements. We thank D. Lawrence and J. Rabalais for technical assistance, R. Powell and G. Hanrahan for nutrient data, and the captain and crew of the RV 'Pelican' for shipboard assistance. Comments from 3 anonymous reviewers helped improve the paper significantly. This research was supported by NASA and the Louisiana Board of Regents through grant number NASA/LEQSF (2001-04), and by the Louisiana Universities Marine Consortium.

\section{LITERATURE CITED}

Alldredge AL, Madin LP (1982) Pelagic tunicates: unique herbivores in the marine plankton. BioScience 32:655-663

Bedo AW, Acuna JL, Robins D, Harris RP (1993) Grazing in the micron and sub-micron particle size range: the case of Oikopleura dioica (Appendicularia). Bull Mar Sci 53:2-14

Berner EK, Berner RA (1987) The global water cycle. Prentice-Hall, Engelwood Cliffs, NJ

Bode A, Dortch Q (1996) Uptake and regeneration of inorganic nitrogen in coastal waters influenced by the Mississippi River: spatial and seasonal variations. J Plankton Res 18:2251-2268

Calbet A (2001) Mesozooplankton grazing effect on primary production: a global comparative analysis in marine ecosystems. Limnol Oceanogr 46:1824-1830

Calbet A, Landry MR (1999) Mesozooplankton influences on the microbial food web: direct and indirect trophic interactions in the oligotrophic open ocean. Limnol Oceanogr 44:1370-1380

Dagg MJ (1988) Physical and biological responses to the passage of a winter storm in the coastal and inner shelf waters of the northern Gulf of Mexico. Cont Shelf Res 8:167-178

Dagg MJ (1995) Copepod grazing and the fate of phytoplankton in the northern Gulf of Mexico. Cont Shelf Res 15:1303-1317

Dagg MJ, Whitledge TE (1991) Concentrations of copepod nauplii associated with the nutrient-rich plume of the Mississippi River. Cont Shelf Res 11:1409-1423

Dagg MJ, Green EP, McKee BA, Ortner PA (1996) Biological removal of fine-grained lithogenic particles from a large river plume. J Mar Res 54:149-160

Evens GT, Paranjape MA (1992) Precision of estimates of phytoplankton growth and microzooplankton grazing when functional response of grazers may be nonlinear. Mar Ecol Prog Ser 80:285-290

Fahnenstiel GL, McCormick MJ, Lang GA, Redalje DG, Lohrenz SE, Markowitz M, Wagoner B, Carrick HJ (1995) Taxon-specific growth and loss rates for dominant phytoplankton populations from the northern Gulf of Mexico. Mar Ecol Prog Ser 117:229-239

Fenchel T (1982) Ecology of heterotrophic microflagellates. II. Bioenergetics and growth. Mar Ecol Prog Ser 8:225-231

Flood PR, Deibel D, Morris C (1992) Filtration of colloidal melanin from seawater by planktonic tunicates. Nature 355:630-632

Fortier L, Le Fèvre J, Legendre L (1994) Export of biogenic carbon to fish and to the deep ocean: the role of large planktonic microphages. J Plankton Res 16:809-839

Froneman PW, Pakhomov EA, Perissinotto R, McQuaid CD (1996) Role of microplankton in the diet and daily ration of Antarctic zooplankton species during austral summer. Mar Ecol Prog Ser 143:15-23

Frost BW, Landry MR, Hassett RP (1983) Feeding behavior of the large calanoid copepods Neocalanus cristatus and $N$. plumchrus from the subarctic Pacific Ocean. Deep-Sea Res 30:1-13

Gaines G, Taylor FJR (1984) Extracellular digestion in marine dinoflagellates. J Plankton Res 6:1057-1061

Gallegos CL (1989) Microzooplankton grazing on phytoplankton in the Rhode River, Maryland: nonlinear feeding kinetics. Mar Ecol Prog Ser 57:23-33

Gallegos CL, Jordan TE (1997) Seasonal progression of factors limiting phytoplankton pigment biomass in the Rhode River estuary, Maryland (USA). I. Controls on phytoplankton growth. Mar Ecol Prog Ser 161:185-198

Gifford DJ (1991) The protozoan-metazoan trophic link in pelagic ecosystems. J Protozool 38:81-86 
Hitchcock GL, Wiseman WJ Jr, Boicourt WC, Mariano AJ, Walker N, Nelsen TA, Ryan E (1997) Property fields in an effluent plume of the Mississippi River. J Mar Syst 12:109-126

Landry MR, Hasset RP (1982) Estimating the grazing impact of marine microzooplankton. Mar Biol 67:283-288

Liu H, Dagg MJ, Campbell L, Urban-Rich J (2003) Picophytoplankton and bacterioplankton in the Mississippi River plume and its adjacent waters. Estuaries (in press)

Lohrenz SE, Fahnenstiel GL, Redalje DG, Lang GA, Dagg MJ, Whitledge TE, Dortch Q (1999) Nutrients, irradiance, and mixing as factors regulating primary production in coastal waters impacted by the Mississippi River plume. Cont Shelf Res 19:1113-1141

Meade RH (1996) River-sediment inputs to major deltas. In: Milliman J, Haq B (eds) Sea-level rise and coastal subsidence. Kluwer, London, p 63-85

Muller H, Geller W (1993) Maximum growth rates of aquatic ciliated protozoa: the dependence on body size and temperature reconsidered. Arch Hydrobiol 126:315-327

Nejstgaard JC, Gismervik I, Solberg PT (1997) Feeding and reproduction by Calanus finmarchicus, and microzooplankton grazing during mesocosm blooms of diatoms and the coccolithophore Emiliania huxleyi. Mar Ecol Prog Ser 147:197-217

Nejstgaard JC, Naustvoll LJ, Sazhin A (2001) Correcting for underestimation of microzooplankton grazing in bottle incubation experiments with mesozooplankton. Mar Ecol Prog Ser 221:59-75

Nival P, Nival S (1976) Particle retention efficiency of an herbivorous copepod, Acartia clausi (adult and copepodite stages): effects on grazing. Limnol Oceanogr 21: $24-38$

Editorial responsibility: Otto Kinne (Editor),

Oldendorf/Luhe, Germany
Redden AM, Sanderson BG, Rissik D (2002) Extending the analysis of the dilution method to obtain the phytoplankton concentration at which microzooplankton grazing becomes saturated. Mar Ecol Prog Ser 226:27-33

Sherr EB, Sherr BF (1994) Bacterivory and herbivory: key roles of phagotrophic protists in pelagic food webs. Microb Ecol 28:223-235

Sherr EB, Sherr BF (2002) Significance of predation by protists in aquatic microbial food webs. Antonie Leeuwenhoek 81:293-308

Stoecker DK, Capuzzo JM (1990) Predation on protozoa: its importance to zooplankton. J Plankton Res 12:891-908

Strickland JDH, Parsons TR (1972) A practical handbook of sea water analysis, 2nd edn. Bull Fish Res Board Can 167: 201-203

Strom SL, Strom MW (1996) Microplankton growth, grazing, and community structure in the northern Gulf of Mexico. Mar Ecol Prog Ser 130:229-240

Turner JT, Tester PA (1989) Zooplankton feeding ecology: nonselective grazing by the copepods Acartia tonsa Dana, Centropages velificatus De Oliveira, and Eucalanus pileatus Giesbrecht in the plume of the Mississippi River. J Exp Mar Biol Ecol 126:21-43

Turner RE, Rabalais NN (1991) Changes in the Mississippi River quality in this century. BioScience 41:140-147

Wiseman WJ Jr, Murray SP, Bane JM, Tubman MW (1982) Temperature and salinity variability within the Louisiana Bight. Cont Mar Sci 25:109-120

Zeldis JR, Davis CS, James MR, Ballara SL, Booth WE, Chang FH (1995) Salp grazing: effects on phytoplankton abundance, vertical distribution and taxonomic composition in a coastal habitat. Mar Ecol Prog Ser 126:267-283

Submitted: February 3, 2003; Accepted: July 15, 2003

Proofs received from author(s): August 18, 2003 